Swarthmore College

Works

1996

\title{
Gender And School Leadership: Using Case Studies To Challenge The Frameworks
}

Lisa Smulyan , 76

Swarthmore College, Ismulya1@swarthmore.edu

Follow this and additional works at: https://works.swarthmore.edu/fac-education

Part of the Education Commons

\section{Recommended Citation}

Lisa Smulyan , 76. (1996). "Gender And School Leadership: Using Case Studies To Challenge The Frameworks". Reshaping Education In The 1990's: Perspectives On Primary Schooling. 169-191. https://works.swarthmore.edu/fac-education/61

This work is brought to you for free by Swarthmore College Libraries' Works. It has been accepted for inclusion in Educational Studies Faculty Works by an authorized administrator of Works. For more information, please contact myworks@swarthmore.edu. 


\title{
11 Gender and School Leadership: Using Case Studies to Challenge the Frameworks ${ }^{1}$
}

\author{
Lisa Smulyan
}

So I'm learning how to be an administrator. I didn't want to be an administrator, either, you know. I sort of got pushed, and it seemed the wrong thing not to do. You know what I mean? It seemed cowardly-and I didn't think they'd pick me. I was as surprised as anybody, and then I kind of thought, 'Well heavens, if they think I can, then I guess I can.' (Interview, October 1991)

In 1989, in her integrating study of women in educational administration, Charol Shakeshaft wrote: 'Histories, case studies, and ethnographies almost always center on the male principal or superintendent. Consequently, we know little of the individual lives of the women who occupy these positions' (p. 56). The quote above describes how one elementary principal entered her job. It represents both her personal story and the experiences of the many women who have entered and worked in the principalship. Individual cases allow us to see the complex interactions between women principals' personal and professional lives and the social and cultural frameworks within which they work.

In this chapter I present a brief overview of some of the prior literature on effective school leadership as well as recent work that examines the role of gender in school administration. The exclusion of gender (and race and class) from work in school leadership makes its generalizations problematic, while the research on women in school administration tends to be limiting in its focus on gender as the determining factor in a woman administrator's experience. Both bodies of literature remain abstracted from the concrete, daily work of school leaders and the immediate choices, decisions, and strategies they use within a dynamic school context. I therefore turn to a case study of a woman principal to illustrate how the characteristics of effective leadership and gender interweave with other personal and professional issues and actions in the ongoing work of a school administrator. 


\section{Theoretical Background}

Many calls for school reform and school restructuring in the late 1980s and 1990s focus on site-based management, developmental/child-centered approaches to teaching, alternative forms of assessment, and teacher empowerment and involvement in decision making. All of these strategies depend on 'effective principals' whose traits, roles, and skills have been described and analyzed by many researchers (Blase and Kirby, 1992; Earth 1990; Blumberg, 1987, 1989; Deal, 1987; Blumberg and Greenfield, 1986). The literature on effective schools suggests that the strong school leader takes initiative; has confidence; tolerates ambiguity; has a clear vision for the school and communicates that vision to teachers, students, and community; sets goals and evaluates them; uses a democratic-participatory style; focuses effectively on people and their needs; and establishes an open, warm and supportive school environment for teachers, students, and parents (Blase and Kirby, 1992; Buell, 1991; Barth, 1990; Griffin, 1990; Porter, Lemon and Landry, 1989; Goodlad, 1984; Sweeney, 1982). Interestingly, the leadership styles described often parallel styles attributed to women administrators by those who examine the role of gender in educational leadership.

None of the general literature on the tasks, roles, and skills of an effective principal addresses the influence of gender (or race or class) on an administrator's actions or interactions. The implication is that all principals experience common demands and need similar strategies to be successful; the primary variables mentioned are school and district cultures and requirements (e.g., Barth, 1990; Blase and Kirby, 1992) and, less frequently, the social, psychological and intellectual history the individual brings to the job (Blumberg, 1987). Blumberg $(1987,1989)$ refers to the latter as the individual's 'baggage,' and comments that despite 'idiosyncrasies' in how each person interprets events and acts in situations, principals' actions and interpretations share a common character: 'that which is personal is generalizable.' Although there are certainly generalizable characteristics of principals and their jobs, calling the effects of gender, race, and class either baggage or idiosyncrasies minimizes the impact of these social constructions and power relationships on both the role of the principalship and the people engaged in it, suggesting that the influences of gender, race, and class are individual interpretations rather than powerful social and political aspects of experience. Yeakey, Johnston and Adkison (1986) and Blackmore (1993) explain the neglect of gender in this literature as the acceptance of the 'rational man' model of organizations which grew out of the emphasis in the early 1900 s on school administrators as professional experts who should run their schools as effective businesses. 'Educational theory and administrative practice have been dominated by men, who have acted as "gatekeepers" in setting the standards, producing the social knowledge and decreeing what is significant, relevent and important in the light of their own experience' (Blackmore, 1993, p. 27). Therefore the body of theory and research on 
educational administration tends to reaffirm the status quo and the existing power structures without questioning them.

The literature on women in educational management focused initially on issues of access and discrimination, then on career development, and more recently on male and female differences in management style. Research on women's access into school administration probes the reasons behind the decreasing numbers of women principals in the past fifty years, especially surprising in light of the large majority of women in the teaching profession. Explanations for women's underrepresentation include discrimination in hiring and promotion; socialization patterns that do not provide women with the skills and behaviors needed for administrative success; women's lack of training, experience, mentorship and support; and women's choice to avoid principalships because of the change in relationship, commitment, and possible role conflicts the position might bring (Edson, 1988; Fauth, 1984; Biklen, 1980; Clement, 1980; Gross and Trask, 1976).

Other studies have examined the similarities and differences in men's and women's career paths into educational administration (Grant, 1989; Shakeshaft, 1989; Edson, 1988; Fauth, 1984; Prolman, 1983; Clement, 1980). This work suggests that the traditional notion of career needs re-examination when applied to many women in education (Smulyan, 1990; Grant, 1989; Sikes, 1985). Women choose teaching, remain in teaching, change as teachers, and enter educational administration in ways that reflect both personal and socio-historical pressures on their lives, and ways which differ from the men whose lives have, for the most part, been used as the norm against which women are examined. For example, research suggests women generally enter teaching with no plans of moving into administration (Polczynski, 1990; Grant, 1989; Sikes, 1985). If they do leave the classroom, it tends to be after many years of teaching-and possibly raising a family-to work in special curriculum areas (e.g., reading, curriculum development) rather than direct school administration (Mitchell and Winn, 1989; Shakeshaft, 1989; Prolman, 1983). Their graduate work is more often in curriculum development, supervision, special education, or counseling than administration (Fauth, 1984; Weber, Feldman and Pling, 1981).

The different career paths of male and female administrators contribute to differences in both the particular roles and tasks they emphasize and the style in which they carry out those tasks (Eagly, Karua and Johnson, 1992; Shakeshaft, 1989; Schmuck, Charters and Carlson, 1981; Gross and Trask, 1976). As school principals, women tend to pay more attention to curriculum, interact more frequently and regularly with students and teachers, involve teachers in decision making, and focus on developing the school as a peoplecentered community than do male administrators (Shakeshaft, 1989; Marshall, 1985; Tibbetts, 1980). Studies that focus on differences in management style tend to dichotomize male and female approaches and skills, emphasizing women's traditional skills of collaboration and care. The focus also, at times, seems to obscure the larger social fabric within which 
people work, providing the impression of a homogeneous cadre of caring, collaborative democratic women leaders.

More recently, studies have begun to focus on the organizational structures of schools and their reflection of larger social structures that perpetuate gender, racial and class inequities. Shakeshaft (1987), Ballou (1989), Marshall (1985) and Adler, Laney and Packer (1993) all argue that the male dominated structures, processes and value systems in society and in schools limit the number of women chosen as administrators and then constrain their actions once hired. 'What is provided is a different view of organizational reality. By grounding organizational social theory in the larger social structures, in the organizational realities from which it emanates, the weight of the evidence reveals that the position of racial minorities and women in organizations is inseparable from the relative position of women and racial minorities in the larger social system' (Yeakey et al., 1986, p. 118). While this approach continues to emphasize a gender difference in style, it locates that difference in larger institutional and social structures, questions its source, and examines its effect on outcomes.

In field as diverse as psychology (Schaef, 1985) and political science (Ferguson, 1984) researchers argue women bring to their work social, interpersonal and institutional experiences that differ significantly from men in society and that operate as subsystems within the larger patriarchal structure. Schaef (1985) argues that the White Male System 'surrounds us and permeates our lives. Its myths, beliefs, rituals, procedures and outcomes affect everything we think, feel, and do' (p. 2). Women live both within their own Female System and yet learn to function within the White Male System in a variety of ways, sometimes by being like men or by acting out the role of the traditional woman. Ferguson (1984) has argued that 'women's experience is institutionally and linguistically structured in a way that is different from that of men' (p. 23). The male bureaucracy, which permeates all public and most private institutions, creates self-perpetuating mechanisms that make it difficult for individuals, especially those in token roles such as women and minorities, to see, let alone resist, the structures. Both Schaef and Ferguson suggest that women can begin to create alternatives once they recognize the larger structures within which they operate, but also describe the limitations on resisting within the existing bureaucracies and structures which characterize institutions such as schools.

Marshall (1985) presents a set of approaches to women educators' dilemma of working within a male dominated structure, approaches which focus on women maintaining their traditionally expected roles while adopting enough of the male ways of functioning to be acceptable. For example, she explains that women can choose 'denial and retreat,' modifying their aspirations, retaining culturally defined roles, and remaining either teachers or childcentered principals who avoid district involvement. Or they can adopt a stance of impressions management: 'Gradually they learn that passing is the only way they can gain tentative acceptance in administrators' and the women's groups. They adopt a grateful, apologetic, supportive, good-natured 
front. This is a front that must be consciously devised and consistently maintained' (Marshall, 1985, p. 44). Thus women learn how to balance being gender appropriate and carrying out the expected administrative tasks in acceptable (i.e., male) ways. Marshall presents no option for women to have a conscious set of goals (e.g., choosing to be a child-centered principal), a vision of how they would like to lead and of the kind of school or district in which they would be most comfortable, and a plan for working toward those goals and visions. She implies that the existing school structure is here to stay and women must learn how to operate successfully within it if they choose to be a part of it. We lose here any sense of the person as an intelligent actor who can, perhaps, see the existing power structure and make choices that allow her to redefine power and how she uses it.

Adler et al. (1993) explain that feminist educators have several options: they can stay in the classroom, avoiding promotion and minimizing the compromises they have to make. They can ascend the career ladder and follow male styles of management, adopting a 'liberal feminist' stance that suggests that women can be as successful as men at their own game, or that androgynous approaches to leadership are most effective (Swiderski, 1988). Alternatively, they can ascend the career ladder and adopt a more female management style, recognizing the possible backlash and difficulties involved. Or, they can leave the profession and continue to work for social change in other ways. Although Adler et al.'s approaches provide a more active, positive approach for women principals, they still focus on gender as the primary (indeed only) influence on the educator's actions and experiences. This perspective, while important, limits our view of the women principals' life and work.

Women and men experience the patriarchal social system and the bureaucratic structures of schools differently. They operate within different constraints and may respond differently within similar situations as a result of actual and perceived differences in status, experience and roles. Women may consciously choose to use gender as a framework as they act and respond as leaders or they may unconsciously make choices that draw on their experience as women in the larger society and the school context. Perhaps leadership approaches described as 'female' can be seen as conscious or unconscious acts of resistance within the larger school and social structures, actions which have the potential to challenge the dominant culture of the school institution and of the larger patriarchal society. While Ferguson (1984) avers that resistance leading to institutional change is close to impossible within existing bureaucratic structures, both Ferguson and Schaef (1985) suggest that developing a feminist discourse which reflects women's experience may lead to the development of a female system which can challenge and redefine the dominant discourse and institutional structures. If women approach leadership as feminists and want to develop different approaches, goals, and processes, they may be frustrated and limited in what they are able to do in the school context. But for many women, their more 'female' management styles may be less conscious. Despite the fact that they may be acting in ways 
which reflect the constraints of the system and their roles in it, they maybe unaware of doing so and, consequently, less likely to challenge the system.

Neither the literature on effective school leaders nor the work on women in educational administration provide a complete picture of the life and work of a woman administrator. Gender is only one variable in determining an individual's leadership style and effectiveness. While gender shapes the female administrator's world view, school and life experience, and modes of interacting with others, it is one of several interacting factors that influences an administrator's behavior and effectiveness (Charters and Jovick, 1981; Schmuck, 1981). In both the individual's life and in the community in which she works, issues of race, ethnicity and class come into play, as do the particular organizational structures in the school district and community and other issues, events and experiences in the life of the individual. The case history approach provides an opportunity to illustrate, challenge, and expand our views of the styles and experiences of women administrators, even as it provides insight into the complexity of elements interacting in an individual's life and work in a school. If, in fact, women's leadership styles match those of effective school leaders, we need to see how those behaviors look when used in the real, complex world of a school by individuals who bring their own personal and professional experiences to the process. Such an examination leads us to question, and perhaps to begin to refine, the categories of effective leaders and women administrators.

\section{Methods}

While qualitative approaches have begun to help us understand the complexity of teachers' lives and work (Cohen, 1991; Weiler, 1988; Connell, 1985), there are few similar examples of the use of these methods to examine the experiences of school administrators (Wolcott, 1973, is the one prominent exception). The case study project from which this chapter is drawn can be categorized generally as ethnography in its use of participant observation, unstructured and structured interviews, and document collection and analysis with the goal of generating a rich description of people's lives and the settings within which they work (Hammersley and Atkinson, 1995; Woods, 1986). I have also drawn on the more specific approaches described as life history and case study research and, more marginally, on some of the recent work done in narrative analysis.

Several recent studies have emphasized the key relationship between teachers' individual, personal identities and their work identities as teachers in a particular school context (MacClure, 1988; Ball and Goodson, 1985; Connell, 1985; Nias, 1985). Life histories suggest that one's sense of self develops before one's teaching career begins, throughout one's personal life, and within one's teaching career. A teacher brings this sense of self to the school and classroom context and is, in turn, influenced by the constraints and possibilities 
determined by a school's management, values, and organization (Ball and Goodson, 1985; Connell, 1985; Nias, 1985). If there are conflicts between one's sense of self and the identity demanded by the teaching situation or school context, the individual may need to change-herself, her context, or her career. How the individual teacher or administrator responds to educational reforms, job changes, and personal challenges is influenced by prior experiences and present values and beliefs, all a part of her identity.

The focus on the interaction between the educator as individual and the school as a social context has led to the reappearance of the life history approach for examining teachers and schooling. This approach, popular in the 1930s, has been revived as a way of providing insight into how an individual's experience influences, and is influenced by, the broader sociohistorical context within which he or she acts (Foster, 1994; Beynon, 1985). In education, in particular, where national directives, local priorities, and school needs are all filtered through the individual teacher or administrator, the life history approach provides important information about how an individual's past and present experience influences his or her actions and responses. As Beynon (1985) says, 'Unless we first understand teachers we can hardly claim to understand teaching' (p. 158). Life history relies on the unstructured interview as a means of data collection, although personal and institutional documents, observation, journals, and other materials can be used to verify and challenge interview data (Burgess, 1984, 1982; Simons, 1981; Bogdan and Taylor, 1970).

In this project, life histories are one key element of each of the three case studies, one of which is presented in this chapter. Robert Stake (1994) describes a case as a bounded, integrated system which has patterned behavior and exists in a significant context. Descriptions of life history and case history approaches appear similar in the literature; like life histories, case studies provide a depth and detail of experience which contribute to our understanding of social institutions, the people within those institutions, and the actions and interactions which occur on a daily basis. They help us locate the individual within her own life experience as well as within the changing historical context which contributes to and reflects that experience (Stake, 1994; Smulyan, 1992; Burawoy, 1991; Goodson, 1991; Ball and Goodson, 1989; Plummer, 1983). More can be learned, case researchers argue, from the detailed description of the particulars of one case than from the comparison of a few attributes across several cases (Stake, 1994; Burawoy, 1991). 'The importance of a single case lies in what it tells us about society as a whole rather than about the population of similar cases' (Burawoy, 1991, p. 281).

Although this study draws on the first person narratives of the principals involved and reflects some of the philosophy behind narrative analysis, it does not use the linguistic approaches that characterize much of this kind of research. Like narrative enquiry, these case studies rely on the voices and reflections of the principals as they tell their stories as a way of discovering the meaning they make out of their experience (Riessman, 1993; Cortazzi, 
1993). Sandra Acker (1990), in an ethnography of a primary headteacher in England, explains that current studies of school management focus on lists of tasks, skills that can be taught, and the fragmentation and unpredictability of the head's day. These studies fail to describe the simultaneous, dramatic quality of events, the detailed content of the activities and the emotions that accompany them, and the sense of the continuation of issues and events over time. Narratives, on the other hand, provide insight into the complexities of the principal's actions and the life of the school. This study weaves the principals' narratives and reflections with the researcher's observations and the reflections of other key constituents-teachers, parents, and other administrators-to create an integrated, complicated picture of the work that goes on in each school.

The larger project from which this chapter is drawn uses life history and case history methods to examine the experiences of three elementary school principals. In each case, I was a participant observer at least once a week in the school for a full school year. During that year I also conducted four to six unstructured life history and career history interviews with each principal as well as more structured interviews with teachers, parents, and other school administrators in that district. By adopting diverse methods of finding, recording, and interpreting data (triangulation) I can develop a more complex picture of the work of each principal in her school.

In order to construct a detailed description of each principal's life history and school experience and effectiveness, I have analyzed the data both during and after data collection using processes described by Becker (1958), Glaser and Strauss (1967), and Schatzman and Strauss (1973). In the first step of this process, preliminary analysis of data indicates salient questions and patterns of experience and action. In the second step, these questions and patterns are used to focus further data collection. Other patterns emerge during this process, and new data are used to clarify, redefine, and assess the accuracy and validity of identified patterns. This process is facilitated by the use of HyperRESEARCH, a new computer program useful in the analysis of qualitative data. In the third step, themes and patterns are incorporated into a case study that is grounded in the data and which can be analyzed using theories of gender and school administration and prior work in school restructuring and change. These cases are shared with the administrators and their responses incorporated into the final case description, thus allowing the subjects a voice in the interpretation of the description and analysis presented.

In gathering data for the case study presented in this chapter, I spent one day a week in 1991-92 as a participant observer 'shadowing' an elementary school principal. I also attended evening meetings of the Home and School organization, Back to School night, district administrative council meetings, faculty meetings and some committee meetings. All observations were documented and annotated. In addition, I conducted six two-to-three hour interviews with the principal which covered life experience and current issues in her work. I interviewed teachers, administrators in the district, and parents 
about their perceptions of the school in general and of the school principal. All interviews were transcribed. The data collected has been analyzed for patterns in the life history and career history of this school principal, and those patterns have been placed within the framework of questions about gender and school administration, effective approaches to school improvement, and the role of case study methods in contributing to principal growth and school change.

\section{The Case}

Jeanne Price has been principal of the Greenfield-Weston Elementary School for five years. The district serves a middle-upper-middle-class, predominantly white community (Greenfield) and a smaller working-class community (Weston). An 'American black' (her term) in her early fifties, Jeanne taught in this same district for twenty years without ever considering a move into school administration. During the past five years she and others say she has learned a great deal and begun to establish a style of leadership and a school atmosphere that clearly reflects her own values and vision for the school. She has, in effect, moved through the stages identified by Parkay, Currie and Rhodes (1992) of socialization experienced by first time principals, focusing first on issues of survival and control, moving through a period of stability and maintenance, and then developing an interest in leadership and professional confirmation in which she focuses on developing a vision for the school and a school atmosphere that allows teachers to work with her toward that vision. 'The pieces are all falling together, that this is an excellent staff, excellent school, and the vision is coming. And the mechanics are in place to start moving to the vision. Five years is a short time, but probably the only amount of time you could do it in' (Interview, June 1992). And yet she realizes that it is not an easy task: 'You've got the vision, so you're scared. And you also have the pride. Like I said, I can't walk away from here until I've done a good job' (Interview, September 1991).

This year, in particular, evidence suggests that she is trying to become a better manager, even as she holds on to the interpersonal approaches and creative emphases that are clearly her hallmark. Questions that arise around this shift include: Do the organizational structures of schools and districts demand a particular management style? Can school principals be effective/ efficient managers and maintain the more cooperative, person-centered approach that they believe in and feel most comfortable with? Jeanne points out that she wants to be able to do what the other administrators (all white males) in the district can do, but she certainly does not want to be the kind of leader she sees in them. When asked if she wanted to become more like one of the other principals she said, 'No-oh my god! No! Oh! No! Maybe inadvertently in places I will become, have some things like him, but I don't want to be like any of them... But there are things about them I think I have 
to be' (Interview, October 1991). It becomes a balance between giving the district and community what they want even as she holds onto her own ideals:

I had an idea about schools and how they should work, but that idea can't be carried out in the structure I work for. So I've had to back off of my ideas, and that sometimes makes me very unhappy. On the other hand, when I'm faced with wanting to escape it or to say, 'I'm not compromising my stuff,' I look at the positive that's happened or the positive input I've been able to get... And then I figure, 'All right. I'll be this kind of principal (the kind the school district wants) and then I'll just run around and do the other stuff.'... I don't want to lose those pieces of me. There are sometimes I think-there are moments when I know I was giving up my soul and some of my ways, but I've been able to recover and find another little niche to worm out in and just go along. (Interview, October 1991)

Lacking role models, paths, patterns, and sometimes support for her own way of operating, she works to forge a new style that integrates effectiveness (in terms of getting what the school needs from the district and within its own operation) and a unique sense of creativity, energy, and care that reflects Noddings' (1988) and others' views of what schools might be.

In this chapter, I choose and follow one story, Jeanne's work with an individual African-American student, that illustrates her approach to leadership. The story reflects her own perspectives, those of teachers, parents and administrators, and the influences of her family, schooling and earlier teaching experiences on actions and decisions. A picture emerges of a woman elementary school principal whose style reflects, to a large extent, that described in the literature on women managers, administrators, and effective school principals, but whose uniqueness clearly results from her own upbringing, personal experience, beliefs about teaching, and unusual (in terms of gender and race) role in the district and community. The school in which she works is effective in terms of student achievement and school climate, but her somewhat indirect style of leadership makes some of those around her wonder what part she plays in that effectiveness. As one parent said, 'If you just took this community, you wouldn't get any straight answer about what this school should look like. So it's partly Jeanne dancing on water to make the school look enough like whatever anyone else wants it to look like, and that's a real time thing, in terms of energy, that's a tough job' (Interview, June 1992).

\section{The Story}

Alan came to Jeanne's attention in October during one of her regular monthly meetings with a first/second grade teacher. When she finished with some other issues she wanted to raise with Emily, she said to her, 'So, tell me 
about your life.' Emily launched into a story of an 8-year-old child in her class who had been held back in kindergarten, did not know his letters, was 'way behind,' and was tested at one point but received no special attention. She spoke very quickly and intensely, angry for the child who had fallen between the cracks and for herself because this child took up a disproportionate amount of her time in the classroom. Jeanne interrupted her along the way, at one point saying, 'What do you like about this kid? What would you like to have happen?' A few minutes later she said, 'I don't even know if you like Alan.'

When Emily finished her story, Jeanne took the floor. She suggested that Emily visit Alan's home, in part because she may have some inaccurate assumptions. She described another African-American child whom she drove home every day and said, 'I see a clean orderly home devoid of literature. There's no chaos. I see his mother who just beams when I say he's doing well.' She told Emily that she is glad it was she (Emily) who discovered him and that she was embarrassed because she (Jeanne) was principal and didn't know about this child even though he is an 'American black child and I lie awake at night thinking I'm going to save them.' Jeanne offered Emily some help in the class and some suggestions for working with Alan for the moment. Toward the end of this mini-lecture, Jeanne said to Emily, 'I hope he [Alan] is in your goals. American black males are dying in the street' (Field notes, 10 July 1991).

Jeanne followed up on this conversation in the following weeks. The reading teacher began to work with Alan, and Jeanne herself tutored him regularly. The school psychologist carried out another core evaluation of Alan, and he and the teachers recommended that the child be transferred to another elementary school in the district where he would be in a self-contained special needs class. Jeanne overrode this decision, saying that they would keep him in her school and meet his needs there. In March, she explained that she met with him nearly every day:

Yeah, I was going to get him a tutor. That was my piece for keeping him here. I didn't know where... I don't want to just let him go to a casual tutor. And it's getting me into whole language too. I read a wonderful article that sounded so convincing. I still think you have to know what you're doing to teach whole language. This article talked about you learn from the company you keep. I loved that phrase. But Alan doesn't put the endings on his words. You've got to teach him to do that. But he's a sweet child, he's got a lot going for him. And I know Emily will be successful. And we'll have him next year. And if you learn by the company you keep, he sure as hell (won't learn) in that special ed class all day. (Interview, March 1992)

Emily, in an interview, explained that she was angry at Jeanne's decision, saying that Jeanne was not aware of this child's low functioning. 'But she 
didn't see his test score and didn't take into account his age. She just looked at his disadvantaged background and the fact that he's black and therefore made special considerations for him' (Interview, April 1992). She also pointed out that there is a larger black population in the other elementary school, which might have provided more of a community for Alan than exists at the Greenfield-Weston School. She was able to see Jeanne's side, however, and said that since Alan seemed to be succeeding, 'Maybe she was really right ... Somebody once said, fair is not always equal. So maybe she's right. Maybe by going out and giving these kids something extra to help them, but it seems unfair that so much energy goes to this small group' (Interview, April 1992).

During the summer, Jeanne arranged for a parent who has close ties to the school to continue tutoring Alan while she was away. This parent and Jeanne have since helped Alan's mother enroll in a General Education Diploma (GED) program to get her high school equivalency degree.

\section{Reflections on the Story}

Jeanne has lived and taught in the Greenfield-Weston district for twenty-five years. She has made a commitment to that school district and has found a comfortable home in this predominantly white community. As a principal, however, she challenges the system, the community and her teachers when it comes to working with black children. Are her actions those of a female administrator? An American black woman? An effective leader for school change?

Jeanne was raised in and around Cincinnati. Her father went to bible school when she was nine and preached on Sundays but always had other jobs during the week. Her mother cleaned houses and raised foster children along with her own. Her parents believed in education; Jeanne attended a rural Catholic school until eighth grade, when her family moved into the city. Following one year in the regular public school, she tested into and attended a public preparatory high school. She went to the University of Cincinnati Teachers College on a scholarship from the school's parent-teacher organization, falling into teaching as she later tripped into the principalship: 'Ever since I was little I wanted to be a nurse but someone gave me a scholarship, so I just walked off.... Everybody I knew and loved were teachers. People I cared about. I fell in love with teachers. They saved my life.... But I didn't plan to be a teacher, and never did I look for any other thing to do' (Interview, October 1991). She also moved away from home during college, after years of growing alienation and what she describes as emotional abuse from her family, especially her mother. Her first teaching job was in the inner city of Cincinnati, where within two years she was given the Cincinnati Teacher of the Year award. She tosses the award aside, saying,

I knew how to make kids mind, you know. And I knew how to organize and I could see what people wanted. I mean, I was a 
manipulator to survive in my own family. And it didn't take me long (as a teacher) to figure out, 'What, you want some of that? I can do that.' That's just how you survive.... I was a good teacher, but I don't know how they found me.... But when I came here (to Greenfield) it was on my resume, because it happened. God, Greenfield took it up and carried it around like it was a gift from the king on a purple platter. (Interview, October 1991)

She moved from Cincinnati to Greenfield with her husband, then had a child and stayed home with him for a few years. She returned to teaching in Greenfield when she and her husband divorced.

Her commitment to working with the black children in the GreenfieldWeston schools has intensified during the past five years, as she is able to use her position as principal to make a difference. It is a personal commitment that comes from her own background-both her experience as an AfricanAmerican woman but also her experience as an abused child:

Whenever I go back to an American black community like home, to my family, or to another school, somewhere where I see the community, my psyche cannot stand it. It is the abuse I suffered there that prevents me from going back there. So, I will never be able to manage that. Never. But I can do something here. I can do something, not only for the American black kids that come here, which I'm just beginning to, after being here three years... But I can also do something for the rest of the population. (Interview, September 1991)

Deciding to stay and work in Greenfield was not always easy to reconcile, and yet she has convinced herself that she has an important job to do here and that she can make an important contribution. Her own ease with her racial identity now allows her to make it an issue, just as the principalship gives her a new platform from which to act.

I know enough about being black that I can be black, you know. I can talk the jive I need, if I need to. I can survive, nobody's going to hurt me walking into town or anywhere else. And I've figured out what I can do here. I had to figure out why, there was a crisis at some point about staying here and I chose to stay teaching here. Because there are enough black kids here... and there were enough white kids who needed to know about me.... And I know how I can be helpful here.... These kids are going to make decisions about a lot of people. For a lot of people. You know, that's input. It's powerful for every new kid that comes here (to see a black woman principal).... I can connect with the black kids right away, you know. But it's got to be different. I know I make a difference for them. (Interview, November 1991) 
Jeanne is, in a sense, reclaiming her connection to the African-American children in this community and choosing to make race an issue in her principalship, bell hooks (1989) talks about this kind of reclamation and choice as both difficult and necessary for creating change. As hooks says, Jeanne may be able to act on these issues at this point in her life because she can step back and examine her past and begin to name her goals:

One of the clear and present dangers that exists when we move outside our class of origin, our collective ethnic experience and enter hierarchical institutions which daily reinforce domination by race, sex and class, is that we gradually assume a mindset similar to those who dominate and oppress, that we lose critical consciousness because it is not reinforced or affirmed by the environment. We must be ever vigilant. It is important that we know who we are speaking to, who we most want to hear us, who we must long to move, motivate, and touch with our words.... Maintaining connections with family and community across class boundaries demands more than just summary recall of where one's roots are, where one comes from. It requires knowing, naming, and being ever mindful of those aspects of one's past that have enabled and do enable one's self-development in the present, that sustain and support, that enrich. One must also honestly confront barriers that do exist, aspects of the past that do diminish, (hooks, 1989, pp. 78-9)

Jeanne's work with Alan, and her focus on African-American children and on a multicultural/multiracial curriculum, reflect a stage in her life when she has both the personal insight and strength and the professional position which allow her to act in ways that, in her mind, make a difference to the individuals, the community of Greenfield-Weston, and the larger social structure.

Edson (1988), in her study of 142 administrative aspirants, found that both affirmative action and community pressure contribute to the hiring of minorities. Some of the minority administrators Edson surveyed believed that even if hired in part because of gender or racial quotas, they would prove their competence once in the job; others felt that they were segregated to assistant or lower level administrative positions as a result of race and gender. Most agreed, however, that competence was responsible for their achievement, not their ethnicity or race (Edson, 1988; Doughty, 1980). Jeanne was somewhat aware of the symbolic and political role of race, gender, and class in her selection as principal; she knew the superintendent wanted her to have the job, 'Because he admired me. Because he's smart, you know, he's no dummy. That's a lot of tickets I bring in. I'm a black female principal. And I live in this town. And the people love me. But underneath it he's a poor, blue collar person too. And it makes him feel good that I've made it because of him' (Interview, October 1991). Thus, Jeanne entered the principalship aware of the issues of race and class, although it is now, in her 
fifth year, that she has chosen to make them a more public issue. Her approach to the principalship is clearly influenced by her own personal and professional background and her consciousness of her racial identity and role as a black woman principal in a predominantly white community.

Jeanne's work with and decisions about Alan also reflect-and challengethe usual expectations of women administrators. Jeanne's movement into the principalship reflects a typical female path of advancement. She taught in the district for twenty years, had no plans to become a principal, and was more than a little surprised when the district selected her. As the brief description of her personal and professional past, above, suggests, this career path results in part from prior experience, but also is determined by her gender (Polczynski, 1990; Mitchell and Winn, 1989; Paddock, 1981). Most male administrators plan to pursue administration as they enter the teaching profession and many teach for only a short time before moving into administrative positions. Networks provide them with support systems that many women lack, and management styles develop out of prior socialization, their comfortable assumption of positions of authority, and the ways in which others expect them to behave. Male administrators often tend to be less interested in classroom issues, individual children, or community building and more interested in district expectations and less personal aspects of administration (Ballou, 1989, Shakeshaft, 1989). As is the case for many women principals, Jeanne's lengthy tenure as a teacher contributes to her concern for individual children, in this case Alan, and perhaps to her sense that his needs could and should be met by the classroom teacher (Shakeshaft, 1989; Charters and Jovick, 1981; Prolman, 1983).

Jeanne's attention to this individual child and her decision to work directly with him is a style more typical of women principals than men (Gross and Trask, 1976). A principal focusing on building management might have agreed to send Alan to another school in the district where he would have been able to take advantage of an existing, effective program. He or she would also have been more likely to use and uphold the administrative process by which that decision was made. Jeanne, again reflecting women's approaches in general, focuses less on immediate effectiveness or traditional rules in this decision and more on the experience of the individual child and her desire to develop and maintain a diverse and supportive community in the school.

In order to keep Alan at the school, however, Jeanne has to pull rank, overriding the decision made by Alan's teacher and the school counselors. Some of the literature suggests that women administrators tend to collaborate with teachers and involve them in a process of democratic decision making (Eagly et al., 1992; Charters and Jovick, 1981). While Jeanne certainly involved Emily in the process of determining Alan's program, she herself decided that he would remain in the school and that she would tutor him. Her unilateral decision-making process is reflected elsewhere in the school, although it is certainly tempered by her work to develop a strong schoolbased management program that involves teachers in all aspects of decision 
making in the school. One area in which she consistently tends to act more independently is in the work she does with individual minority children and in promoting multicultural awareness throughout the school. For example, students and teachers have a monthly meeting or assembly, during which they develop the school's theme, recognize outstanding students, and watch students perform. Each month the school works on a poem, and several months in a row, Jeanne asked all the students to memorize Langston Hughs' poems. This, in conjunction with her attention to African-American students in the schools, has made some of the teachers uncomfortable.

I've never seen her mothering the poor white kids, the way she would a poor black one. I don't know that that's bad at all. But going to the home, bringing them here, it's wonderful that a principal would do that. But I haven't seen her do it for other kids.... It doesn't seem right. Maybe it is uncomfortable-it's embarrassing, and I'm not sure why. To hear her gleam about teaching Alan-any kid would want tutoring.... And I think the more global picture is that she's right, we've got to do something. We've got to do something. But I'm not sure she should do it in the school where she's the principal. I think it sets up all kinds of social conflicts for the child. (Interview, March 1992)

Other teachers are comfortable with Jeanne's looking out for individual minority students and multicultural issues in general, seeing it both as natural and as a benefit to the school: 'As much as she's proud of her heritage, she's very much interested in everyone else's culture. So, she's really well-rounded like that. And I don't, I think it's more interest than a bias, really' (Interview, June 1992).

Jeanne herself became aware of some of the teachers' discomfort with her championing of African American kids, and although she was not about to give up her more direct approach to this set of issues, chose to address it in ways which again reflect a female approach to management, one which emphasizes communication, interpersonal interactions, and participation (Shakeshaft, 1989; Charters and Jovick, 1981). At a faculty meeting she raised with teachers her concern that they might not bring black children to her attention because she might think they were prejudiced or because she might act on her own without listening to their views. It was not at this point a topic for discussion, but more an opening of the issue, with Jeanne owning her own prior actions and saying that perhaps it was a problem in her own perception of the issues. Her willingness to open up the topic for discussion reflects a concern for her continued interpersonal relationships with these teachers, because through those relationships she runs the school. Even in an area where she tends to be less collaborative in her style, she is at least aware of the responses of others and thinking about how to include them in a conversation about the decisions she makes. It is not clear that this overture led to further conversation or addressed teachers' discomfort, however. It 
could be seen as a conversation opener or as a conscious or unconscious move by Jeanne to let people know that she knew of their discomfort but wanted to keep it under control.

Alan's story also has, for Jeanne, implications for school reform. In particular, ideas for two changes have grown out of this experience, ideas that will take time to develop and implement, but which reflect the vision Jeanne has of the school as a place that can serve all students in exciting and challenging ways. First, Jeanne wants to find ways to make the school a more supportive community for its African-American (and other minority) children and a more diverse community for all of the children at GreenfieldWeston. In the fall of 1992 she gathered together a group of parents and professionals to talk about the possibility of developing a tuition-free program through which minority students outside of the district could attend the school. The group opposed this idea, but has continued to work with Jeanne to develop multicultural curriculum and approaches at the school that would better serve the needs of the majority and minority students who are there.

Second, Jeanne has been developing ideas of how to better meet the needs of students identified as in need of special education. She has begun with a small summer tutoring program for Alan and a few other students, hoping to expand it into a full-year school for these children, in particular, but also for any students who need and want it. She is also interested in examining both the special education program and the classroom process to see how to better meet the children's needs. From thinking about Alan, her thoughts move to other children and to new programs:

So I'm talking about Alan, I'm talking about special ed and the goal. He just personifies what the other kids have. And the richness of their environment prevents us from having them often; they're being taken care of or learning to compensate in some other way. But we need to be ready to do it here, within the school year, the context of the school day, and be more flexible.... The other piece, now this is the vision part, is that I'm really looking forward to having a Tradewinds School (local school for able children with reading disabilities) here. And I want to, and I probably told you this, ask Bob Welsh when he comes, 'Before you retire, Bob, I want a ropes course here.' So he'll be working from a physical standpoint.... And that's leading into the extra stuff for kids who need the confidence to learn. (Interview, June 1992)

Her ideas here are very much at the level of speculation. In practice, several parents have expressed concern about the school's lack of response to their children's special needs both within and outside of the classroom. But as a school leader, Jeanne is beginning to develop a vision, and a possible set of programs to meet it. It is a vision based on meeting the needs of students and teachers (but students first) and developing a school community that is diverse, supportive, and focused on growth. And it is a vision that grows out 
of her experiences as a child, a teacher, an African-American and a woman. It remains to be seen whether she can translate this vision into practice.

How did I get to be this principal? It's bewildering, you know. I don't know how the hell I got to be a principal. When I talk to people about how I came along-I look back and I think it was very ordinary and it was an escape from other things. But in fact, it was doing all the things that got me to be here. And it never occurred to me that it was a rich path. And yet it was very rich. And I've been looking over a rainbow trying to figure out, you know, how to have a rich life beyond and it's right here. So now I want people to know, 'Kids, that what you're doing right now is, is rich and right.' (Interview, October 1993)

\section{Conclusions}

In response to the calls in the 1970s and 1980s for school reform that emphasized the content of change, many recent studies have examined the process of change (Lieberman and Miller, 1990). These studies document the critical importance of collaboration, teacher participation, and a focus on practical issues in effective school improvement. Practices associated with successful innovations include the opportunity for teachers to interact around professional issues, the provision of technical assistance, the adaptation of ideas and programs toward a fit with school and classroom regularities, and opportunities for reflection (Griffin and Barnes, 1984). These studies emphasize the need to develop a professional, supportive work environment for teachers that parallels a positive climate of learning for students. School change only occurs if the individuals most closely involved and affected are engaged in meaningful and positive ways (Smulyan, 1990).

In order to understand how to make collaboration work, how to engage teachers in the process of change, how to establish a positive school environment, we need to know more about school leaders and their ways of working toward effective schools. The current literature on effective school principals focuses on the traits, roles, and skills which characterize good leaders. These attempts to encapsulate or propose static models for the dynamic process of leadership that we see in Jeanne's case run into problems; this research still lacks a sense of what leadership looks and feels like in action. The literature also loses some of its credibility by its neglect of issues of race, class and gender, because teachers, students, and administrators all function within personal, school and larger social contexts where these aspects of self and role influence actions, reactions, beliefs and values.

Recent work examining the relationships between gender and school administration provides some insight into the complexity of leadership. We see a school principal's actions and responses as a part of her experience 
within a social and bureaucratic system which may make her more conscious of power relations, more aware of the roles and experiences of those around her, and more interested in developing alternative management approaches which allow her to neither dominate nor be dominated. This literature also has its limitations; women experience the existing power structures and their own gender differently. Little of this literature, for example, points out that the patriarchal system is also white and middle class. In Jeanne's case, race is a crucial determinant of many of her actions and responses, often modifying or dominating responses which may otherwise be seen as gender related. Women of different generations, religions, and social classes, women who have had varied life experiences and who work in different school environments will face unique challenges and will respond to them in unique ways. The work done on gender and school administration makes us more aware of the complexities in describing effective leaders, but it, too, may limit our view.

Any list of leadership characteristics, gender-based or otherwise, reveals only a small part of what it means to be an effective principal. To say that Jeanne is female, African-American, focused on individual children, and concerned about relationships with teachers and with developing a democratic management style only begins to provide a sense of what it would be like to teach and work with her. For example, we see a unique intersection of influences of race and gender in her approach to working with Alan; her commitment to working with and for African-American children at this point in her career modifies her usual more collaborative approach to working with teachers. As she develops her vision of what the school could and, she believes, should be, she tries to develop a style that allows her to work with others to achieve that vision. It seems possible that a more participatory or democratic style of leadership would be ineffective in meeting some of Jeanne's goals for both African-American and white children in the school. She therefore needs to develop leadership skills that allow her to involve others in decision making even as she remains more directive in some areas of concern. Thus, literature suggesting that effective principals are democratic or that women administrators tend to focus on interpersonal issues and use more collaborative rather than directive approaches, oversimplify a complicated process. It remains interesting that prescriptions for effective school leaders tend to match descriptions of women's leadership styles, but we need to see more of how those behaviors look when applied within the real, complex world of a school by individuals who bring their own personal and professional experiences to the process.

Case studies such as this one begin to illustrate the complex interaction of the many variables that influence a school administrator's goals and actions. Future research in educational administration needs to continue to examine the lives and work of the individuals involved in schools to understand how lists of traits, roles, and skills of effective administrators translate into responses to children, teachers, parents, and other administrators; into ideas and actions; and into school practice in a particular context that may lead to change. 


\section{Note}

1 Research for this project was supported by the Spencer Foundation and by Swarthmore College.

\section{References}

ACKER, S. (1990) 'Managing the drama: The headteacher's work in an urban primary school,' Sociological Review, 38, pp. 247-71.

ADLER, S., LANEY, J. and PACKER, M. (1993) Managing Women, Milton Keynes, Open University Press.

BALL, SJ. and GOODSON, I.F. (1985) 'Understanding teachers: Concepts and contexts,' in BALL, S. and GOODSON, I. (eds) Teachers' Lives and Careers, London, Falmer Press, pp. 1-26.

BALLOU, M. (1989) 'Male administrative orientation: Patriarchy in school administration,' Contemporary Education, 4 (60), pp. 216-17.

BARTH, R. (1990) Improving Schools from Within, San Francisco, Jossey Bass.

BECKER, H. (1958) 'Problems of inference and proof in participant observation,' American Sociological Review, 23, pp. 652-60.

BEYNON, J. (1985) 'Institutional change and career histories in a comprehensive school,' in BALL, S. and GOODSON, I. (eds) Teachers' Lives and Careers, London, Falmer Press, pp. 158-79.

BIKLEN, S. (1980) 'Introduction: Barriers to equity-women, educational leadership, and social change,' in BIKLEN, S. and BRANNIGAN, M. (eds) Women and Educational Leadership, Lexington, MA, DC Heath and Co., pp. 158-79.

BLACKMORE, J. (1993) 'In the shadow of men: The historical construction of educational administration as a "masculinist" enterprise,' in BLACKMORE, J. and KENWAY, J. (eds) Gender Matters in Educational Adminstration and Policy, London, Falmer Press, pp. 27-48.

BLASE, J. and KIRBY, P. (1992) Bringing Out the Best in Teachers, California, Corwin Press.

BLUMBERG, A. (1987) 'The work of principals: A touch of craft', in GREENFIELD, W. (ed.) Instructional Leadership, MA, Allyn and Bacon, pp. 38-55.

BLUMBERG, A. (1989) School Administration as a Craft, Boston, MA, Allyn \& Bacon.

BLUMBERG, A. and GREENFIELD, W. (1986) The Effective Principal: Perspectives on School Leadership, Boston, MA, Allyn \& Bacon.

BOGDAN, R. and TAYLOR, SJ. (1970) Introduction to Qualitative Research Methods, New York, John Wiley and Sons.

BUELL, N. (1992) 'Building a shared vision: The principal's leadership challenge,' NASSP Bulletin, 76, pp. 88-92.

BURAWOY, M. (1991) 'The extended case method,' in GAMSON, J., BURAWOY, M., BURTON, A., FERGUSON, A., Fox, K., HURST, L., JULIUS, N., KURZMAN, C., SALZINGER, L. and SCHIFFMAN, J. (eds) Ethnography Unbound, Berkeley, University of California Press, pp. 271-87.

BURGESS, R.G. (1982) Field Research: A Sourcebook and Field Manual, London, George Allen and Unwin.

BURGESS, R.G. (1984) In the Field: An Introduction to Field Research, London, George Allen and Unwin.

CHARTERS, W.W. and JOVICK, T.D. (1981) 'The gender of principals and principalteacher relations in elementary schools', in SCHMUCK, P., CHARTERS, W.W. and CARLSON, R. (eds) Educational Policy and Management, NY, Academic Press, pp. 307-31. 
CHUSMIR, L.H. (1989) 'Male-female differences in the association of managerial style and personal values,' The Journal of Social Psychology, 129 (1), pp- 65-78.

CLEMENT, J. (1980) 'Sex bias in school administration', in BIKLEN, S. and BRANNIGAN, M. Women and Educational Leadership, Lexington, MA, DC Heath and Co., pp. 131-38.

CLEMENT, J. (1981) 'Sex bias in school administration,' in BIKLEN S. and BRANNIGAN, M. (eds) Women and Educational Leadership, Lexington, MA, DC Heath and Co., pp. 131-8.

COHEN, R.M. (1991 A Lifetime of Teaching: Portraits of Five Veteran High School Teachers, NY, Teachers College Press.

CONNELL, R. (1985) Teachers Work, London, Allen and Unwin.

CORTAZZI, M. (1993) Narrative Analysis, London, Falmer Press.

DEAL, T. (1987) 'Effective school principals: Counselors, engineers, pawn brokers, poets...or instructional leaders?' in GREENFIELD, W. (ed.) Instructional Leadership, Boston, MA, Allyn \& Bacon, pp. 230-48.

DENZIN, N.K. (1989) Interpretive Biography, California, Sage Publications.

DOUGHTY, R. (1980) 'The black female administrator: Woman in a double bind,' in BIKLEN, S. and BRANNIGAN, M. (eds) Women and Educational Leadership, Boston, DC Heath and Co., pp. 165-74.

EAGLY, A.H., KARUA, S.J. and JOHNSON, B.T. (1992) 'Gender and leadership style among school principals: A meta-analysis,' Educational Administration Quarterly, 28 (1), pp. 76-102.

EDSON, S. (1988) Pushing the Limits: The Female Administrative Aspirant, Albany, SUNY Press.

FAUTH, G. (1984) 'Women in educational administration: A research profile,' The Educational Forum, 49 (1), 65-79.

FERGUSON, K. (1984) The Feminist Case Against Bureaucracy, Philadelphia,Temple University Press.

FOSTER, M. (1994) 'Resisting racism: Personal testimonies of African-American teachers', in WEIS, L. and FINE, M. (eds) Beyond Silenced Voices: Class, Race and Gender in United States Schools, Albany, NY, State University of New York Press, pp. 273-88.

GLASER, B. and STRAUSS, A.L. (1967) The Discovery of Grounded Theory, London, Weidenfeld and Nicolson.

GOODLAD, J. (1984) A Place Called School, NY, McGraw Hill.

GOODSON, I. (1991) 'Teachers' lives and educational research,' in GOODSON, I. and WALKER, R. (eds) Biography, Identity, and Schooling, London, Falmer Press, pp. 13749.

GRANT, R. (1989) 'Alternative model of "career",' in ACKER, S. (ed.) Teachers, Gender and Careers, London, Falmer Press, pp. 35-50.

GRIFFIN, G. (1990) 'Leadership for curriculum improvement: The school administrator's role,' in LIEBERMAN, A. (ed.) Schools as Collaborative Cultures: Creating the Future Now, London, Falmer Press, pp. 195-212.

GRIFFIN, G. and BARNES, S. (1984) 'School change: A craft-derived and researchbased strategy,' Teachers College Record, 86 (1), pp. 103-23.

GROSS, N. and TRASK, A.E. (1976) The Sex Factor and the Management of Schools, NY, John Wiley and Sons.

HAMMERSLEY, M. and ATKINSON, P. (1995) Ethnography: Principles in Practice, New York, Routledge.

hOOKS, B. (1989) Talking Back, Boston, South End Press.

LIEBERMAN, A. and MILLER, L. (1990) 'Restructuring schools: What matters and what works,' Phi Delta Kappan, June, pp. 759-64.

MACCLURE, M. (1988) 'Teachers' jobs and lives: An interim report,' Centre for Applied Research in Education, University of East Anglia. 
MARSHALL, C. (1985) 'The stigmatized woman: The professional woman in a male sex-typed career,' Journal of Educational Administration, 23 (2), pp. 131-52.

MITCHELL, J.P. and WINN, D.D. (1989) 'Women and school administration,' Journal of Instructional Psychology, 16, pp. 54-71.

NIAS, J. (1985) 'A more distant drummer: Teacher development as the development of self,' in BARTON, L. and WALKER, S. (eds) Education and Social Change, London, Croom Helm, pp. 3-28.

NODDINGS, N. (1988) 'An ethic of caring and its implications for instructional arrangements,' American Journal of Education, 96 (2), pp. 215-29.

PADDOCK, S. (1981) 'Male and female career paths in school administration,' in SCHMUCK, P., CHARTERS, W. and CARLSON, R. (eds) Educational Policy and Management, New York, Academic Press, pp. 187-98.

PARKAY, F.W., CURRIE, G.D. and RHODES, J.W. (1992) 'Professional socialization: A longitudinal study of first-time high school principals,' Educational Administration Quarterly, 28 (1), pp. 43-75.

PLUMMER, K. (1983) Documents of Life, London, George Allen \& Unwin.

POLCZYNSKI, M. (1990) 'Getting there', Momentum, 21, pp. 28-30.

PORTER, A.W., LEMON, D.K. and LANDRY, R.G. (1989) School climate and administrative power strategies of elementary school principals,' Psychological Reports, 65, pp. 1267-71.

POWELL, G.N. (1988) Women and Men in Management, Newbury Park, Sage Publications.

PROLMAN, S. (1983) 'Gender, career paths, and administrative behavior.' Paper presented at the Annual Meeting of AERA, Montreal.

REGAN, H. (1990) 'Not for women only: School administration as a feminist activity,' Teachers College Record, 91 (4), pp. 565-77.

RIESSMAN, C.K. (1993) Narrative Analysis, Newbury Park, CA, Sage Publications.

ROGERS, J.L. (1988) 'New paradigm leadership: Integrating the female ethos,' Initiatives, 51 (4), pp. 1-8.

SCHAEF, A.W. (1985) Women's Reality: An Emerging Female System in a White Male Society, San Francisco, Harper and Row.

SCHATZMAN, L. and STRAUSS, A.L. (1973) Field Research: Strategies for a Natural Sociology, Englewood Cliffs, NJ, Prentice Hall.

SCHMUCK, P. (1981) 'The sex dimension of school organization: Overview and synthesis,' in SCHMUCK, P., CHARTERS, W.W. and CARLSON, R. (eds) Educational Policy and Management, NY, Academic Press, pp. 221-34.

SCHMUCK, P., CHARTERS, W.W. and CARLSON, R. (eds) (1981) Educational Policy and Management, NY, Academic Press.

SHAKESHAFT, C. (1987) 'Theory in a changing reality', Journal of Educational Equity and Leadership, 7 (1), pp. 4-20.

SHAKESHAFT, C. (1989) Women in Educational Administration, NY, Sage.

SIKES, P. (1985) 'The life cycle of the teacher', in BALL, S. and GOODSON, I. (eds) Teachers' Lives and Careers, London, Falmer Press, pp. 27-60.

SIMONS, H. (1981) 'Conversation piece: The practice of interviewing in case study research,' in ADELMAN, C. (ed.) Uttering Muttering, London, Grant Mclntyre Ltd., pp. 27-50.

SMULYAN, L. (1990) 'Moving the mountain: The individual and school change.' Paper presented at the Implementing Educational Change Conference, Centre for Educational Development, Appraisal and Research, University of Warwick.

SMULYAN, L. (1992) 'The artist as INSET coordinator: A problem in design,' Journal of Teacher Development, 1 (2), pp. 95-110.

STAKE, R. (1994) 'Case studies,' in DENZIN, N. and LINCOLN, Y. (eds) Handbook of Qualitative Research, California, Sage.

STATHAM, A. (1987) 'The gender model revisited: Differences in the management styles of men and women,' Sex Roles, 16 (7/8), pp. 409-29. 
SWEENEY, J. (1982) 'Research synthesis on effective school leadership', Educational Leadership, 39 (5), pp. 346-52.

SWIDERSKI, W. (1988) 'Problems faced by women in gaining access to administrative positions in education', Education Canada, 28, pp. 24-31.

TIBBETTS, S. (1980) 'The woman principal: Superior to the male,'Journal of the NAWDAC, 43 (4), pp. 15-18.

WEBER, M., FELDMAN, J. and PLING, E. (1981) 'Why women are underrepresented in educational administration,' Educational Leadership, 38 (4), pp. 320-2.

WEILER, K. (1988) Women Teaching for Change: Gender, Class and Power, MA, Bergin and Harvey.

WOLCOTT, H. (1973) The Man in the Principal's Office, IL, Waveland Press.

YEAKEY, C., JOHNSTON, G. and ADKISON, J. (1986) 'In pursuit of equity: A review of research on minorities and women in educational administration,' Educational Administration Quarterly, 22 (3), pp. 110-49. 